Relations industrielles

Industrial Relations

\title{
Hyman, Jeff. Training at Work : A Critical Analysis of Policy and Practice
}

\section{Denis Morin}

Volume 48, numéro 3, 1993

URI : https://id.erudit.org/iderudit/050882ar

DOI : https://doi.org/10.7202/050882ar

Aller au sommaire du numéro

Éditeur(s)

Département des relations industrielles de l'Université Laval

ISSN

0034-379X (imprimé)

1703-8138 (numérique)

Découvrir la revue

Citer ce compte rendu

Morin, D. (1993). Compte rendu de [Hyman, Jeff. Training at Work : A Critical Analysis of Policy and Practice]. Relations industrielles / Industrial Relations, 48(3), 577-581. https://doi.org/10.7202/050882ar

Tous droits réservés (C) Département des relations industrielles de l'Université Laval, 1993
Ce document est protégé par la loi sur le droit d'auteur. L'utilisation des services d'Érudit (y compris la reproduction) est assujettie à sa politique d'utilisation que vous pouvez consulter en ligne.

https://apropos.erudit.org/fr/usagers/politique-dutilisation/ 
sélectif du nom et de l'adjectif organization aurait su communiquer une association, une interprétation, une transposition plus faciles quant aux leçons à retenir par les ministères et les organismes des secteurs public, parapublic et péripublic. (Loin de nous l'idèe de suggérer aux auteurs de référer, de discuter même de cas ou d'exemples québécois... Ce livre doit se vendre à New York et ailleurs!)

Quoi de neuf dans ce livre ? Le lecteur diplômé depuis les cinq dernières années (sinon davantage) de facultés ou d'écoles d'administration publique ou privée et de départements d'informatiques y verront une belle synthèse des enseignements qui leur ont été offerts par les modules des SI. Contrairement aux prétentions exprimées lors des premières phrases des auteurs, ils - et DMR! - n'ont pas tout inventé. Mais il ne faut pas leur en vouloir. La compétition est féroce! Nous ne référons pas aux recherches et aux enseignements universitaires, mais plutôt aux autres firmes de consultants! $\dot{A}$ titre d'exemple, Edward Yourdon, le président de la célèbre firme new-yorkaise (qui porte son nom) vient tout juste de décrire le World-class software organization dans un livre qui est plus orienté vers la programmation et le développement de logiciels (Decline \& Fall of the American Programmer, Englewood Cliffs, New Jersey: Yourdon Press, 1992). Il y a aussi l'ouvrage de Patrick Smith, le directeur de la technologie chez SHL Systemhouse, qui discute de l'informatique "client/serveur " et où l'on peut lire dès la première phrase de l'avant-propos : «Un transfert (shift) fondamental est en voie de se réaliser quant à la façon dont les businesses se servent des systèmes d'information pour leur avantage compétitif " (Client/Server Computing, Carmel, Indiana: SAMS Publishing, 1992). Combien d'autres livres de ce genre - la compétition aidant! - sont maintenant disponibles ou paraîtront sous peu...

Rolland Hurtubise

École nationale d'administration publique

Training at Work: A Critical Analysis of Policy and Practice, by Jeff Hyman, London, Routledge, 1992, 191 p., ISBN 0-415-05343-9.

Worker training has taken on particular importance at the present time given a variety of forces: globalization and specialization in world markets, changing organizational structures, new ways of organizing work, higher skills required at entry level positions, new technologies, changes in the labour force, professionnel obsolescence. Training should be seen as a mechanism for investing in human capital to assist a country in improving its competitiveness.

Although the title of this volume may give the impression that the book is a training manual or a compendium of training techniques, this is not the case. Hyman's book is not a comprehensive and practical guide to the employee training process (i.e. training needs assessment, training design, training methods, maximizing trainees learning, evaluating training program). The volume by Wexley and Latham (1991) or the extensive updated review by Goldstein (1992) represent more comprehensive treatments of the training process. 
Nevertheless, Jeff Hyman's book does a masterful job of describing the current training situation in Britain. The discussion is particularly strengthened by the findings of an empirical investigation into training. The result is an articulate and insightful explanation on why British industry fails to train.

Hyman persuasively argues that Britain's low level of economic growth is directly associated with the failure to train. Given the circumstances in which Britain finds itself today, he urges dramatic change in Britain's approach to training and offers some valuable ideas on how to improve training practices and policies so as to enhance the overall economic standing of British industry. Undoubtedly, British industry will have to take a more direct interest in worker training to maximize its utilisation of actual and potential human resources. Given British industry's need for more sophisticated management - an essential requirement to compete in worldwide markets - training and development activities should be accelerated. Given these realities, Hyman endorses a provocative package of reforms of national training policy. For example, he powerfully addresses critical issues concerning the fundamentally important role of government intervention. Hence, the chief contribution of this book is that it clearly highlights the relationship between training and broader concern relating to productivity, economic development and competitiveness.

The book has nine chapters and is divided into two parts. In the first part, containing four chapters, the author provides a wide-ranging explanation of the reasons for the historical failure to train. The book is worth reading for this part alone.

Among the most interesting segments of the book is the informative introductory chapter, which provides the background and sets the context for the rest of the book. Hyman provides the reader with an interesting discussion of training as an implicit part of the employment relationship. The author makes the valid point that productivity is an inherent part of the processes of industrial relations. The most logical step to enhance productivity is to focus on training. Training is required for British industry to be competitive.

Unfortunately, training has been a neglected dimension of the employment relationship in Britain: the state has been committed to neutrality in the training area; training has not received much attention from employers; and unions have been passive in their approach to bargaining training provisions. Hyman forcefully point out that training is a distributive process best resolved through active pluralist involvement by the parties. Ultimately, training can be seen as an area of employment relations defined by a combination of convergent and divergent interest. Convergent in the sense that both employers and unions should emphasize training opportunities as a solution to work issues, but divergent in that employers and unions interests as regards training provisions are not identical. Therefore, training should be incorporated into collective bargaining. The state must encourage training as an essential feature of employment relations if training is really to be an effective means of increasing national productivity. It is likely that competitive pressures will force the state to a redirection of training policy. Hyman finds that the parties involvement in policy making and the enforcement of national training policy is necessary. 
The first chapter highlights the critical economic problems facing Britain. Hyman suggests that the traditional government and employer strategy of reducing labour costs has not resulted in increased national competitiveness. The neglect of training and industrial relations which accompanied the trend of deregulation actually exarcebated the economic weaknesses of Britain. Hyman proposes a far better approach to achieve competitiveness, namely that investment in training may protect or create an economically profitable position for British industry.

Chapter 2 provides a detailed description of recent industrial relations reforms as part of a liberalization of both product markets (notably in the public sector) and the labour market. Government reforms have sought to reduce collective influence at work through encouraging labour market individualism. A elitist education system reform sensitive to labour market demands was introduced with similar intentions. This education reform had the objective of increasing the role of employers in the educational process. Considering the close relationship between education and training, Hyman attempt to determine whether education reforms have had any discernable effect on employers responsibility to promote training initiatives. In fact, it turns out that employers have failed to meet the training challenge. What follows is an extensive discussion of how the overall lack of competence of Britain managers has contributed directly to Britain's poor economic performance. Finally, Hyman draws attention to some of the problems associated with the growing skill shortage, including the fact that the labour force is undereducated relative to other countries, and that a qualified labour force is particularly essential if British firms are to compete successfully in world markets.

Chapter 3 is devoted to manpower policy. Rather than adopt a policy in which the state actively helps to coordinate the management of manpower, Britain has tended to rely upon promoting voluntary training arrangements between employers and employees, primarily geared to satisfying the immediate production needs of employers. Hyman demonstrates that this non-interventionist approach is not capable of remedying the deficiencies in skills and qualification in Britain. The market dominated policy approach to training and the absence of government controls have together worked against employers taking the long-term steps required to reconstruct the skills and educational base needed by the economy.

In recognition of the importance of a comparative perspective on the topic, Chapter 4 contains an overview and comparison of training practices in use in Western Europe, the U.S.A. and Japan. Hyman points out that Britain undertrains its workforce relative to these other countries.

Part two is comprised of 5 chapters which report empirical work on British training practices. Hyman concludes this point of the book by proposing an alternative strategy which would attempt to put in place a more substantial training and vocational education framework based on government responsibility for overall coordination of these training activities.

In light of the public policy analysis on voluntary employer responsibility for training, Chapter 5 examines the extent to which employers have discharged with their responsibilities. This chapter contains an impressive inventory and interesting analysis of studies of British training practices. Four major points emerge from this solid and 
critical review. Hyman reports that employers training efforts were dominated by shortterm considerations and a minimalist training tradition. It would also appear that training activities have a low organizational status. Abundant evidence suggests that employers actually adopt a cost centered approach to training rather than treating it as an investment. Finally, the author shows quite convincingly that British organizations are managed by poorly educated and trained executives. Such an attitude toward training if it persists may prove to be detrimental to the ability of British industry to successfully compete with nations whose organizations place a higher value on training.

Chapters 6 and 7 present the results of an ambitious and important research project conducted by the author. However, one would wish to know a little more about the survey - its development, validity, and so on. The methods are not described in sufficient details. It would have been worthwhile to gather qualitative data as well.

The results of the survey indicate that trainers have insufficient knowledge in human resource management and training. The training department has not exerciced leadership within the British organization. In the face of increasing foreign competition, firms must incorporate training and development explicitly into strategic planning efforts devoted to finding new markets, improving product quality and applying new technology. Training should support the strategic direction of the organisation, and training objectives should be aligned with organizational goals. The strategic focus with regard to training is not a prevailing pattern in British organizations. Only in larger organizations do human resource management specialists fully participate in top-level training decisions. British organisations do not spend much on training. To regain the competitive edge in world markets, British employers will have to invest more in training and development activities. Management development is either very new or nonexistent in most British organisations. Little evidence was found of formal involvement of employees in training decisions. The survey has provided well documented evidence that small organisations do not maintain formal, planned training programs for employees and managers. The most serious difficulty is the severe shortage of qualified managers, professionals and experienced technicians.

The final two chapters draw upon the accumulated evidence to demonstrate the flimsiness of the argument for a market based-approach to resolve Britain's deeply rooted skills weaknesses. Hyman recommends a more proactive and comprehensive national training policy in order to ensure the continuous development of the skills of the British work force. Moreover, he correctly emphasizes that training is an appropriate area for joint regulation. Government should therefore introduce mechanisms that deal with the conflicting interests of the state, employees and employers regarding training, and reconcile them in a constructive form.

In sum, this book presents a balanced and objective portrayal of the current training situation in Britain. Some of the chapters are significant scholarly contributions, all are solidly informative, thought-provoking and well written. The range and breadth of the topics covered in the book are impressive. There are important and profound insights into each of the topics dealt with. However, Hyman doesn't really take the lead in suggesting important research issues. Obviously, this book will be of most interest to professors of human resource management and has much to offer for those interested 
in the subject. This reviewer feels that this welcomed synthesis on training practices in Britain will be hard to top.

Denis MORIN

Université Laval

Jurisprudence commentée en droit du travail, de 1898 à nos jours, par Fernand Morin, Montréal, Les éditions Yvon Blais inc., 1992, 860 p., ISBN 2-89073-818-3

La fonction primordiale d'une décision judiciaire est de rendre la justice, de trancher le litige privé qui oppose des parties ayant des intérêts hégémoniques. Il faut reconnaître que tant au niveau de l'opinion publique que de la doctrine philosophique, il y antériorité et prééminence de l'idée de justice sur celle du droit (Bruno Huisman et François Ribes, Les Philosophes et le Droit, Paris, Bordas, 1988, 380 p.). Dans la société féodale, les nobles comme les vassaux s'adressaient au roi pour obtenir réparation. « La justice du roi, c'est de n'opprimer injustement personne [...], d'être le défenseur des étrangers, des orphelins et des veuves, de réprimer les vols, punir les adultères, défendre les églises, nourrir les pauvres [...] vivre en Dieu et en toutes choses. " (Le concile de Paris de 828). Par la suite, partant du principe de la délégation royale, les juges seigneuriaux purent devenir des professionnels de la justice. Et ainsi, la production littéraire des juges, soit la jurisprudence, prît naissance. Pour les praticiens du droit du travail une décision n'a pas pour seul but que de rendre la justice, elle se doit de dire le droit. En somme, les sujets de droit deviennent objet. De nos jours, une décision judiciaire est véritablement un objet puisqu'elle fait œuvre de précédent. De là, la nécessité de bien connaître les décisions qui ont marqué l'histoire des relations du travail. Cette connaissance est importante non seulement d'un point de vue phénoménologique mais également pratique, car il appartient aux tribunaux administratifs et de droit commun, par le biais de l'évocation, d'assurer le passage de la règle législative abstraite à une application concrète. Ainsi, les tribunaux ne font pas seulement que dire le droit, à plusieurs égards, ils font la règle de droit. Dans cette démarche de la connaissance historique des décisions judiciaires, le professeur Morin, grâce à son dernier ouvrage, nous fait franchir de grands bonds.

L'auteur nous propose rien de moins que de présenter, analyser, commenter et parfois critiquer les 100 jugements qui, à ses yeux, sont les plus marquants en droit du travail. Par marquants, l'auteur entend ceux qui ont le plus « contribué, à leur manière respective, à façonner, moduler ou orienter le droit du travail québécois ». Ces échantillons cibles furent choisis sur un espace temps d'un siècle de pratique judiciaire. Les décisions furent également choisies en fonction de huit thèmes bien précis : partage des compétences et liberté publique (23) ; décrets et normes minimales du travail (6); contrat individuel du travail (13); syndicat/accréditation et négociation (36); moyen de pression: grève et lock-out (20); convention collective (16); arbitrage de griefs et contrôle judiciaire (43) ; accidents du travail (3). (Certaines décisions se retrouvent dans plusieurs thèmes.) 